\title{
Cognitive status among patients with chronic obstructive pulmonary disease
}

\author{
This article was published in the following Dove Press journal: \\ International Journal of COPD \\ 16 March 2016 \\ Number of times this article has been viewed
}

\author{
Carlos Roncero' \\ Ana Isabel Campuzano 2 \\ Jose Antonio Quintano ${ }^{3}$ \\ Jesús Molina ${ }^{4}$ \\ Joselín Pérez ${ }^{2}$ \\ Marc Miravitlles ${ }^{5}$ \\ 'Addiction and Dual Diagnosis \\ Unit, Psychiatry Department, Vall \\ d'Hebron Hospital-ASPB. Ciber \\ de Salud Mental (CIBERSAM) and \\ Department of Psychiatry and Legal \\ Medicine, Universidad Autónoma \\ de Barcelona, Barcelona, Spain; \\ ${ }^{2}$ Medical Department, Grupo Ferrer, \\ Barcelona, Spain; ${ }^{3}$ Primary Care \\ Center Lucena I, Lucena, Cordoba, \\ Spain; ${ }^{4}$ Primary Care Center Francia, \\ Dirección Asistencial Oeste, Madrid, \\ Spain; ${ }^{5}$ Department of Pneumology, \\ Hospital Universitari Vall d'Hebron. \\ Ciber de Enfermedades Respiratorias \\ (CIBERES), Barcelona, Spain
}

Correspondence: Carlos Roncero Department of Psychiatry and Legal Medicine, Universidad Autónoma de Barcelona. Passeig Vall d'Hebron, I 19-129, 08035 Barcelona, Spain Tel +34934894880 Fax +34934894587 Email croncero@vhebron.net
Purpose: We investigated the association between cognitive impairment and chronic obstructive pulmonary disease (COPD), taking into account demographic and clinical variables evaluated during routine practice.

Patients and methods: We performed a post hoc analysis of a cross-sectional study that included subjects with stable COPD. Sociodemographic and clinical information was recorded using the Body mass index, airflow Obstruction, Dyspnea and Exacerbations index and the Charlson comorbidity index. Cognitive performance was studied by the mini-mental state examination, with a score less than 27 indicating clinical impairment. Depressive symptoms, physical activity, and quality of life (EuroQoL-5 dimensions and COPD Assessment Test) were also evaluated.

Results: The analysis included 940 subjects. The prevalence of cognitive impairment was $39.4 \%$. Multivariate logistic regression models revealed that cognitive impairment was associated with educational level (odds ratio $[\mathrm{OR}]=0.096,95 \%$ confidence interval $[\mathrm{CI}]=0.011-0.447$ ) and poorer quality of life measured by the EuroQoL- 5 dimensions social tariff (OR $=0.967,95 \%$ $\mathrm{CI}=0.950-0.983$ ). When questionnaires were not included in the analysis, cognitive impairment was associated with educational level ( $\mathrm{OR}=0.063,95 \% \mathrm{CI}=0.010-0.934)$, number of exacerbations $(\mathrm{OR}=11.070,95 \% \mathrm{CI}=1.450-84.534)$, Body mass index, airflow Obstruction, Dyspnea and Exacerbations index score $(\mathrm{OR}=1.261,95 \% \mathrm{CI}=1.049-1.515)$, and the Charlson comorbidity index $(\mathrm{OR}=1.412,95 \% \mathrm{CI}=1.118-1.783)$.

Conclusion: Cognitive impairment is common in COPD and is associated with low educational level, higher disease severity, and increased comorbidity. This could have therapeutic implications for this population.

Keywords: chronic obstructive pulmonary disease, cognitive function, mini-mental state examination, depression, quality of life, comorbidity

\section{Introduction}

Chronic obstructive pulmonary disease (COPD) is characterized by progressive and partially reversible airflow limitation, and it is among the leading causes of mortality worldwide. ${ }^{1}$ COPD is a multicomponent disease, and patients present a range of comorbidities that have an impact on prognosis and may increase the risk of mortality. ${ }^{2}$ The effects of COPD on respiratory and physical function have been well studied; moreover, due to the heavy burden of psychological disturbance, psychiatric morbidity, and disability in daily life, the mental health of COPD patients has received growing attention in recent years. ${ }^{3,4}$ The prevalence of cognitive impairment in patients with COPD ranges from $12 \%$ to $88 \%{ }^{5}$ and is associated with depression, poor quality of life, which may affect patients' ability to manage their disease, and reduced compliance with medication and oxygen therapy, ${ }^{6,7}$ leading to adverse clinical outcomes. ${ }^{8-11}$ 
Therefore, cognitive function as well as emotional function are important aspects of the overall clinical care of patients with COPD.

It has been suggested that a multidimensional assessment and personalized disease management approach could be an optimal strategy for addressing comorbidities, selfmanagement education, and risk factor modification in COPD patients. $^{7}$ The early identification of cognitive dysfunction is critical if outcomes are to be improved in this population, and an understanding of the characteristics associated with a higher risk of cognitive impairment may assist health care professionals to address this challenge.

The primary aim of this study was to examine the crosssectional prevalence of cognitive impairment in an unselected population of COPD patients; the secondary objective was to determine the relationships between cognitive impairment and major demographic and clinical variables, such as lung function, depression, and quality of life.

\section{Materials and methods}

\section{Study design and sample}

The present study is a post hoc analysis of a cross-sectional, observational study conducted in respiratory medicine departments and primary care centers in Spain. ${ }^{11}$ This study was aimed at examining the prevalence of depressive symptoms and moderate-to-severe depression in COPD and included ambulatory patients who were 40 years of age or older, with stable COPD (confirmed by postbronchodilator forced expiratory volume in 1 second/forced vital capacity $<70 \%$ and absence of exacerbations in the previous 3 months). All patients that completed the mini-mental state examination (MMSE) were included in this post hoc analysis. The study was approved by the Institutional Ethics Committee of the Hospital Clinic (Barcelona, Spain) and was conducted in accordance with the principles of the Declaration of Helsinki. Prior to participation, all patients signed written documentation that the informed consent process was completed.

\section{Study assessments}

Investigators recorded patients' sociodemographic data and clinical information on COPD severity using the Modified Medical Research Council Dyspnea scale ${ }^{12}$ and the Body mass index, airflow Obstruction, Dyspnea and Exacerbations (BODEx) index, ${ }^{13}$ comorbidity according to the Charlson index, ${ }^{14}$ exacerbations in the previous year, and treatment. Cognitive status was assessed by the MMSE, ${ }^{15,16}$ widely used to screen for cognitive impairment. This instrument explores spatial and temporal orientation, registration, attention, and calculation, recall, language, and visual construction in
12 items and 30 questions. A correct answer to one question was given 1 score point (total from 0 to 30 ). A score of less than 27 indicated cognitive impairment. ${ }^{17}$

Depressive symptoms were measured using the short Beck Depression Inventory questionnaire. ${ }^{18,19}$ This tool is a 13-item self-administered inventory that assesses affective, cognitive, motivational, and vegetative symptoms of depression. Items use a 4-point scale that ranges from 0 to 3 and a total score is calculated by adding up the item responses. An additional question was included about suicidal ideation and suicidal attempts.

Health-related quality of life was assessed by the generic EuroQoL-5 dimensions (EQ-5D) questionnaire and the specific COPD Assessment Test (CAT). The EQ-5D consists of a 5-item descriptive system (including mobility, self-care, usual activities, pain/discomfort, and anxiety/depression), with each item rated as no problems, some problems, or severe problems, and an overall health state score for the day of the assessment, measured on a visual analog scale (0-100; 100 represents best overall health). ${ }^{20}$ The CAT is a short, specific quality of life questionnaire for measuring the impact of COPD on the patient's well-being and daily life. It consists of eight items, each presented as a 6-point semantic differential scale, providing a score out of 40 , indicating the impact of the disease. ${ }^{21}$ We used the validated Spanish version of CAT. ${ }^{22}$ Physical activity was measured by asking patients how many minutes, on average, they walked every weekday, as previously described..$^{23,24}$ Depending on their daily walking activity, patients were classified into three groups: patients who walked $<30$ minutes, patients who walked between 30 and 60 minutes, and patients who walked $\geq 60$ minutes.

\section{Statistical analysis}

Continuous variables were expressed as the mean and the standard deviation. Categorical values were described as absolute and relative frequencies. Fisher's exact test was used for comparisons of qualitative variables, with the Bonferroni correction for all pairwise comparisons. Student's $t$-test was used to determine the relationship between qualitative variables by group. Odds ratio (OR) univariates were calculated by logistic regression to evaluate the different risks contemplated in the study, including all demographic, clinical, and questionnaires variables. Only significant associations are shown in the Tables 2 and 3. After stepwise analysis, the various adjusted ORs were calculated using multivariate logistic regression. The first model was developed with cognitive status as a dependent variable and all variables that showed a significant association with cognition in univariate 
analysis as independent variables (model 1). A second model (model 2) excluded any variables derived from the use of the questionnaires from the independent variables. The objective of model 2 was to identify the factors associated with cognitive impairment that could be identified in routine clinical practice without the administration of questionnaires.

All statistical tests were considered significant when $P$ was $<0.05$. Statistical analyses were performed using SAS version 9.1.3 Service Pack 3 software (SAS Institute Inc., Cary, NC, USA).

\section{Results \\ Sample characteristics and cognitive status}

Of 1,273 screened patients, 333 had not had the MMSE evaluation and were excluded from the analysis. Both populations (excluded and included ones) were compared and their characteristics are described in Table 1. Included patients were predominantly male, with an age ranging from 40 to 90 years. A total of 370 patients $(39.4 \%)$ scored below the threshold of 27 for suspicion of mild cognitive impairment

Table I Characteristics of all patients with and without cognitive impairment according to MMSE scores

\begin{tabular}{|c|c|c|c|c|c|}
\hline Variable & Excluded patients & Included patients & MMSE $<27$ & MMSE $\geq 27$ & $P$-value \\
\hline Sex, males (n, \%) & $233(73.1 \%)^{\mathrm{a}}$ & $762(81.6 \%)$ & $299(81.7 \%)$ & $463(81.5 \%)$ & $>0.99$ \\
\hline Age, years (mean, SD) & $66.8(9.4)$ & $67.7(10.0)$ & $69.6(9.5)$ & $66.5(10.1)$ & $<0.001$ \\
\hline \multicolumn{6}{|l|}{ Coexistence (n, \%) } \\
\hline Alone & $55(17.1 \%)$ & 121 (I3.0\%) & $50(13.6 \%)$ & 71 (12.5\%) & \multirow[t]{5}{*}{$<0.001^{\mathrm{b}}$} \\
\hline With partner & $212(66.0 \%)$ & $646(69.2 \%)$ & $224(61.0 \%)$ & $422(74.4 \%)$ & \\
\hline With family & $47(14.6 \%)$ & |4| (I5.1\%) & $75(20.4 \%)$ & $66(11.6 \%)$ & \\
\hline Institutionalized & I $(0.3 \%)$ & $12(1.3 \%)$ & $8(2.2 \%)$ & $4(0.7 \%)$ & \\
\hline With professional caregiver & $6(1.9 \%)$ & $14(1.5 \%)$ & $10(2.7 \%)$ & $4(0.7 \%)$ & \\
\hline \multicolumn{6}{|l|}{ Educational level (n, \%) } \\
\hline Basic literacy & $47(14.7 \%)^{\mathrm{a}}$ & $74(7.9 \%)$ & $42(11.4 \%)$ & $32(5.7 \%)$ & \multirow[t]{4}{*}{$<0.001^{c}$} \\
\hline Primary level & $190(59.6 \%)$ & $540(57.9 \%)$ & 251 (68.4\%) & $289(5 \mathrm{I} .1 \%)$ & \\
\hline Secondary level & $62(19.4 \%)$ & $193(20.7 \%)$ & $52(14.2 \%)$ & |4| (25.0\%) & \\
\hline Completed university & $20(6.3 \%)^{\mathrm{a}}$ & $125(13.4 \%)$ & $22(6.0 \%)$ & $103(18.2 \%)$ & \\
\hline COPD duration (mean, SD) & $10.4(6.4)$ & $11.6(7.7)$ & $12.9(8.0)$ & $10.8(7.4)$ & $<0.001$ \\
\hline Active smoker (n, \%) & $77(25.8 \%)$ & $206(22.4 \%)$ & $66(18.4 \%)$ & $140(25.0 \%)$ & $>0.99$ \\
\hline Pack-years (mean, SD) & 37.1 (20.4) & $39.5(21.8)$ & $42.3(24.8)$ & $37.7(19.4)$ & 0.002 \\
\hline BMI (mean, SD) & $27.5(4.7)$ & $27.8(4.7)$ & $27.9(4.7)$ & $27.7(4.7)$ & 0.52 \\
\hline \multicolumn{6}{|l|}{ Postbronchodilator spirometry (mean, SD) } \\
\hline FVC, $\mathrm{mL}$ & $2,945(977)$ & $3,046(977)$ & $2,912(922)$ & $3,132(1,001)$ & 0.001 \\
\hline FVC, \% & $65.4(21.2)^{\mathrm{a}}$ & $71.0(17.0)$ & $71.3(15.8)$ & $70.8(17.70)$ & 0.55 \\
\hline $\mathrm{FEV}_{\mathrm{l}}, \mathrm{mL}$ & $\mathrm{I}, 805(846)$ & $1,886(852)$ & $\mathrm{I}, 778(767)$ & $\mathrm{I}, 957(897)$ & 0.002 \\
\hline $\mathrm{FEV}_{1}, \%$ & $54.4(21.0)$ & $55.2(17.8)$ & $55.7(17.9)$ & $54.9(17.7)$ & 0.59 \\
\hline $\mathrm{FEV}_{\mathrm{I}} / \mathrm{FVC}$ & $56.6(16.0)$ & $58.5(20.9)$ & $57.2(13.8)$ & $59.4(24.4)$ & 0.13 \\
\hline Cough $(n, \%)$ & $264(85.7 \%)$ & $770(83.2 \%)$ & $322(89.7 \%)$ & 448 (79.1\%) & $<0.001$ \\
\hline Expectoration (n, \%) & $233(78.4 \%)$ & $669(73.0 \%)$ & $286(79.7 \%)$ & $383(68.7 \%)$ & $<0.001$ \\
\hline Dyspnea, (n, \%) & $296(94.0 \%)$ & 891 (95.0\%) & $359(97.5 \%)$ & $532(93.3 \%)$ & 0.003 \\
\hline mMRC dyspnea score (mean, SD) & $2.8(0.9)$ & $2.8(0.9)$ & $3.1(0.9)$ & $2.6(0.9)$ & $<0.001$ \\
\hline Patient with exacerbations (n, \%) & $265(79.6 \%)^{a}$ & $808(86.0 \%)$ & 351 (94.9\%) & $457(80.2 \%)$ & $<0.001$ \\
\hline $\begin{array}{l}\text { Number of hospital-treated exacerbations } \\
\text { (emergency + admission) (mean, SD) }\end{array}$ & $\mathrm{I} .3(0.5)^{\mathrm{a}}$ & $1.4(2.2)$ & $\mathrm{I} .8(2.7)$ & $\mathrm{I} .0(\mathrm{I} .5)$ & $<0.001$ \\
\hline Oxygen therapy at home, $(n, \%)$ & $65(23.0 \%)$ & $204(23.4 \%)$ & $130(37.0 \%)$ & $74(14.2 \%)$ & $<0.001$ \\
\hline BODEx (mean, SD) & $2.7(1.8)$ & $2.8(1.9)$ & $3.3(1.8)$ & $2.4(1.9)$ & $<0.001$ \\
\hline Charlson comorbidity index (mean, SD) & $\mathrm{I} .3(1.4)^{\mathrm{a}}$ & $\mathrm{I} .4(\mathrm{I} .4)$ & $1.6(1.5)$ & $1.0(0.6)$ & $<0.001$ \\
\hline BDI score (mean, SD) & $9.3(6.1)$ & $9.0(6.5)$ & II.7 (6.4) & $7.2(5.7)$ & $<0.001$ \\
\hline Suicidal ideation (n, \%) & $29(9.4 \%)$ & $123(13.1 \%)$ & $78(21.2 \%)$ & $45(7.9 \%)$ & $<0.001$ \\
\hline Health status according to EQ-5D (mean, SD) & $57.9(17.1)$ & $57.4(19.2)$ & $52.4(18.2)$ & $60.5(19.2)$ & $<0.001$ \\
\hline Social tariff EQ-5D (mean, SD) & $0.6(0.2)$ & $0.6(0.2)$ & $0.5(0.2)$ & $0.7(0.2)$ & $<0.001$ \\
\hline CAT score (mean, SD) & $21.6(7.3)$ & $21.6(8.6)$ & $25.2(6.9)$ & $19.3(8.7)$ & $<0.001$ \\
\hline Physical activity grade (mean, SD) & $4.1(1.6)$ & $4.3(1.5)$ & $3.7(1.4)$ & $4.6(1.5)$ & $<0.001$ \\
\hline Minutes walked per day (mean, SD) & $73.5(68.2)^{\mathrm{a}}$ & $64.2(52.3)$ & 56.I (45.8) & $68.8(55.2)$ & 0.001 \\
\hline
\end{tabular}

Notes: a Excluded vs included patients. ${ }^{b}$ Alone vs professional caregiver. 'Basic literacy vs completed university.

Abbreviations: BDI, Beck Depression Inventory; BMI, body mass index; BODEx, Body mass index, airflow Obstruction, Dyspnea and Exacerbations index; CAT, COPD Assessment Test; COPD, chronic obstructive pulmonary disease; EQ-5D, EuroQoL-5 dimensions; FEV , forced expiratory volume in I second; FVC, forced vital capacity; mMRC, Modified Medical Research Council scale; MMSE, mini-mental state examination; SD, standard deviation. 


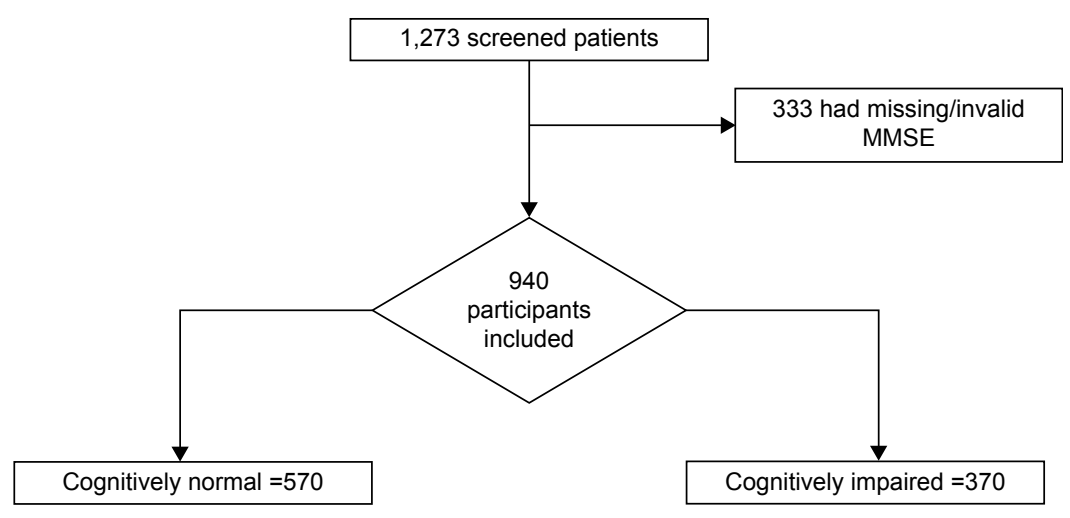

Figure I Flow diagram for the analysis.

Abbreviation: MMSE, mini-mental state examination.

(MCI; Figure 1). Patients with MMSE scores $<27$ were older, had a lower level of formal education, had heavier smoking exposure, presented more respiratory symptoms, had more frequently domiciliary oxygen, suffered a higher number of and more severe exacerbations during the previous year, and had a greater comorbidity burden. In addition, higher levels of depression, more suicidal ideation, poorer quality of life, and less physical activity were more frequent in cognitively impaired patients.

\section{Factors associated with the presence of cognitive impairment}

In the univariate analysis, cognitive impairment was associated with higher age, lower educational level, worse lung function and more severe COPD, more frequent respiratory symptoms and exacerbations, and oxygen therapy requirement. Higher comorbidity burden, more depressive symptoms, and more impaired health status (EQ-5D and CAT) were also associated with cognitive impairment. Higher levels of physical activity were associated with better cognitive function (Table 2).

In the multivariate analysis, only educational level and the EQ-5D social tariff were independently and significantly associated with cognitive impairment (Table 2). When the analysis was limited to the usual demographic and clinical variables, and the questionnaires were excluded from the model, the significant factors in the multivariate analysis were educational level, history of exacerbations,

Table 2 Factors associated with cognitive impairment in univariate and multivariate analysis

\begin{tabular}{|c|c|c|c|c|c|c|}
\hline \multirow[t]{2}{*}{ Variable } & \multicolumn{3}{|c|}{ Univariate } & \multicolumn{3}{|c|}{ Multivariate } \\
\hline & OR & $95 \% \mathrm{Cl}$ & $P$-value & OR & $95 \% \mathrm{Cl}$ & $P$-value \\
\hline Age (per 5-year increment) & 1.177 & $1.099-1.262$ & $<0.001$ & & & \\
\hline $\begin{array}{l}\text { Educational level } \\
\text { (completed university vs basic literacy) }\end{array}$ & 0.160 & $0.080-0.310$ & $<0.001$ & 0.069 & $0.011-0.447$ & 0.014 \\
\hline Postbronchodilator FVC & 0.977 & $0.963-0.99 \mid$ & 0.001 & & & \\
\hline Postbronchodilator FEV, & 0.975 & $0.959-0.99 \mid$ & 0.003 & & & \\
\hline Cough & 2.290 & $1.540-3.410$ & $<0.001$ & & & \\
\hline Expectoration & 1.780 & $1.300-2.430$ & $<0.001$ & & & \\
\hline Presence of dyspnea (yes vs no) & 2.850 & $1.360-5.960$ & 0.005 & & & \\
\hline Exacerbations in the previous year (yes vs no) & 4.570 & $2.750-7.570$ & $<0.001$ & & & \\
\hline Oxygen therapy & 3.180 & $1.070-9.440$ & 0.037 & & & \\
\hline BODEx & 1.280 & $1.179-1.389$ & $<0.001$ & & & \\
\hline Charlson comorbidity index & 1.590 & $1.435-1.762$ & $<0.001$ & & & \\
\hline BDI score & 1.125 & $1.098-1.152$ & $<0.001$ & & & \\
\hline Suicide ideation & 3.150 & $2.120-4.670$ & $<0.001$ & & & \\
\hline Health status according to EQ-5D & 0.799 & $0.742-0.860$ & $<0.001$ & & & \\
\hline Social tariff EQ-5D & 0.971 & $0.965-0.977$ & $<0.001$ & 0.967 & $0.950-0.983$ & $<0.001$ \\
\hline CAT score & 1.098 & $1.078-1.118$ & $<0.001$ & & & \\
\hline Physical activity grade & 0.648 & $0.587-0.715$ & $<0.001$ & & & \\
\hline Minutes walked per day & 0.994 & $0.991-0.998$ & 0.001 & & & \\
\hline
\end{tabular}

Abbreviations: BDI, Beck Depression Inventory; BODEx, Body mass index, airflow Obstruction, Dyspnea and Exacerbations index; CAT, COPD Assessment Test; Cl, confidence interval; EQ-5D, EuroQoL-5 dimensions; FEV , forced expiratory volume in I second; FVC, forced vital capacity; OR, odds ratio. 
Table 3 Factors associated with cognitive impairment in univariate and multivariate analysis, including only demographic and clinical variables

\begin{tabular}{|c|c|c|c|c|c|c|}
\hline \multirow[t]{2}{*}{ Variable } & \multicolumn{3}{|c|}{ Univariate } & \multicolumn{3}{|c|}{ Multivariate } \\
\hline & OR & $95 \% \mathrm{Cl}$ & $P$-value & OR & $95 \% \mathrm{Cl}$ & $P$-value \\
\hline Age (per 5-year increment) & 1.177 & $1.099-1.262$ & $<0.001$ & & & \\
\hline $\begin{array}{l}\text { Educational level } \\
\text { (completed university vs basic literacy) }\end{array}$ & 0.160 & $0.080-0.310$ & $<0.001$ & 0.063 & $0.010-0.394$ & 0.010 \\
\hline Postbronchodilator FVC & 0.977 & $0.963-0.991$ & 0.001 & & & \\
\hline Postbronchodilator FEV, & 0.975 & $0.959-0.991$ & 0.003 & & & \\
\hline Cough & 2.290 & $1.540-3.410$ & $<0.001$ & & & \\
\hline Expectoration & 1.780 & $1.300-2.430$ & $<0.001$ & & & \\
\hline Dyspnea & 2.850 & $1.360-5.960$ & 0.005 & & & \\
\hline Exacerbations & 4.570 & $2.750-7.570$ & $<0.001$ & 11.070 & I.450-84.534 & 0.020 \\
\hline Oxygen therapy & 3.180 & $1.070-9.440$ & 0.037 & & & \\
\hline BODEx & 1.280 & $1.179-1.389$ & $<0.001$ & 1.261 & $1.049-1.515$ & 0.014 \\
\hline Charlson comorbidity index & 1.590 & $1.435-1.762$ & $<0.001$ & 1.412 & $1.118-1.783$ & 0.004 \\
\hline Suicide ideation & 3.150 & $2.120-4.670$ & $<0.001$ & & & \\
\hline Physical activity grade & 0.648 & $0.587-0.715$ & $<0.001$ & & & \\
\hline Minutes walked per day & 0.994 & $0.991-0.998$ & 0.001 & & & \\
\hline
\end{tabular}

Abbreviations: BODEx, Body mass index, airflow Obstruction, Dyspnea and Exacerbations index; $\mathrm{Cl}_{\text {, confidence interval; } \mathrm{FEV}}$, forced expiratory volume in I second; FVC, forced vital capacity; OR, odds ratio.

the BODEx index, and the Charlson comorbidity index (Table 3).

\section{Discussion}

COPD is a multicomponent inflammatory disease that affects physical and nonphysical functions, one of which is cognition. In our study, we found some degree of cognitive impairment in almost $40 \%$ of unselected COPD patients, as determined by a MMSE score $<27$. Previous estimates of cognitive dysfunction in COPD patients ranged from $12 \%$ to $88 \%$, depending on the study population and the tools used for neuropsychological assessment. ${ }^{5,9}$ A recent study in a very similar population (including not only elderly patients, but also young patients) to ours ${ }^{17}$ found MCI in $36 \%$ of COPD patients after comprehensive neuropsychological testing. The authors reported that a MMSE score of 27 provided optimal maximum accuracy and a diagnostic cutoff $(<27$ indicated impairment), with $97 \%$ specificity and $73 \%$ of patients correctly classified. However, they also found that the Montreal Cognitive Assessment performed better as a screening test for detecting MCI in patients with COPD. So, this threshold for mild impairment is not necessarily indicative of a clinically significant cognitive decline associated with functional impairment, but could serve as an early identification of an affected cognitive function.

Cognitive symptoms are core symptoms in many mental disorders; ${ }^{25}$ they impact on cognitive functioning, which deteriorates as patients get older, particularly after the age of $60 .{ }^{26}$ COPD patients score lower on standard cognitive performance tests over time, compared with individuals of the same age without the disease. ${ }^{27}$ One hypothesis for this accelerated decline in COPD patients is altered brain perfusion. ${ }^{28}$ Changes in brain perfusion due to hypoxemia in subjects with severe COPD may increase cognitive impairment. ${ }^{29}$ In our population, more cognitively affected patients were receiving domiciliary oxygen that could be a correlate of higher disease severity and sustained periods of hypoxemia. In contrast, a recent study indicated that longterm home oxygen therapy allowed to preserve cognitive functions from the COPD-induced deterioration, ${ }^{30}$ so the role of supplemental oxygen in preventing COPD-induced cognitive deterioration is still controversial. Indeed, other factors, such as hypercapnia or oxidative stress, may also be involved. ${ }^{31}$ Other authors have suggested that intermittent and continuous hypoxia resulting from poor lung function may lead to transient deficits in neurotransmitter metabolism in the central nervous system. ${ }^{32-34}$ Several mechanisms, then, appear to be involved in cognitive decline in this population. Prospective neuroimaging studies are required to characterize brain changes and corresponding disturbances in cognitive function in these patients over time.

Cognitive impairment represents a critical health care burden in terms of costs..$^{35}$ Individuals with MCI have a higher risk of developing dementia than the general population. ${ }^{36}$ Moreover, cognitive dysfunction in COPD has been associated with poorer outcomes and even with an increase in disability and mortality. ${ }^{8,37,38}$ Thus, it is essential that this condition is identified early in COPD patients, in order to 
prevent or delay progression to clinical dementia or increased morbidity. If the factors affecting cognition are recognized, cognitive impairment may be detected earlier and COPD patients at higher risk may be identified. In our study, the multivariate analysis showed that educational level and quality of life assessed by EQ-5D were significantly and independently associated with the presence of cognitive impairment. However, the use of health-related quality of life or other questionnaires is not a routine practice in most primary care offices, so we ran a multivariate model, discarding the scores of these questionnaires and including only demographic and clinical variables. In this model, cognitive impairment was associated with exacerbations in the previous year, the severity of COPD measured by the BODEx index, and a higher comorbidity burden.

Exacerbations in COPD are of great importance. They have been associated with increased health care costs, ${ }^{39}$ a significant decline in health status, ${ }^{40}$ and substantial mortality. ${ }^{41}$ Our results suggest that frequent exacerbations also have negative consequences on cognitive function. This is in line with a previous study that investigated the cognitive function of COPD patients who were hospitalized following an acute exacerbation. These patients had significantly poorer cognitive function compared with control participants 3 months after discharge from the hospital. ${ }^{10}$ Other studies have shown that cognitive impairment during the exacerbation period resolves during periods of stability. ${ }^{42-44}$ More exacerbations and increased COPD severity could reflect the poorer compliance with medication associated with cognitive impairment. ${ }^{6,7}$ The systemic inflammation seen in severe COPD and during acute exacerbations ${ }^{45}$ may participate in neurocognitive impairment via a direct neurotoxic effect or by affecting cerebral atherosclerosis. ${ }^{9}$ A high comorbidity burden may also contribute to persistent brain injury: multiple concomitant diseases, such as cerebrovascular disease and related mechanisms, including endothelial dysfunction and oxidation, may lead to neuronal death, synaptic dysfunction, and cognitive impairment. ${ }^{46}$

All these data confirm that the cognitive impairment that occurs in COPD patients is associated with disease severity. Neuropsychiatric assessment should become a routine part of the diagnostic procedure for these patients, to help physicians grade the overall impact of COPD and determine the most effective treatment and strategies.

The cross-sectional design of our study limits any type of causal inferences, and the directionality between COPD and cognition remains unclear. Despite the frequent use of the MMSE in clinical research and practice, this tool for cognitive impairment detection could have missed key domains of cognition often affected in COPD (ie, executive functioning). An additional limitation of our study is the lack of data on our patients' medical treatment. As treatment may have great impact on the symptom burden and mental health of the patients, such information should be collected in future studies. In particular, prospective studies are urgently needed to determine the most effective behavioral and medical interventions for reducing the risk of poor neurocognitive outcomes in patients with COPD.

\section{Conclusion}

Cognitive impairment is common in COPD and has important clinical implications. Early detection of cognitive decline is crucial, in view of its association with poorer COPD outcomes, including increased mortality, and patients with frequent exacerbations and or when the BODEx index appears concerning the clinician may want to ask the patient and/or caregivers about cognitive function. These patients may need more individualized educational and care interventions to help them manage their daily lives. Clinicians must involve family caregivers in the care plan of patients with severe COPD and cognitive deficits.

\section{Acknowledgments}

The authors wish to acknowledge the role of Saned in study monitoring and statistical analysis. The authors would also like to thank the following investigators for participating in the Factors Associated with Depression in Patients with COPD (DEPREPOC) study: Ada Luz Andreu, Adolfo García Molné, Ahmad Khalaf Ayash, Alberto Saura Vinuesa, Alejandra Marín Arguedas, Alejandro García Huete, Alejandro Muñoz Fernández, Alfons Torrego Fernández, Alfonso Van Der Eynde Collado, Alfredo González Panizo, Alfredo Pérez Cortada, Alicia Catalán Salelles, Alicia Marín Tapia, Alicia Taboada Duro, Alvaro Ortega Gutierrez, Alvaro Pérez Gómez, Amin Shubbi Shehebar, Amparo Alaban Ibáñez, Ana Boldova Loscertales, Ana Fortuna Gutierrez, Ana Luisa Kersul, Andrés Huete Martos, Andres Sánchez Barón, Angel Lara Font, Angels Puigdollers Rovellat, Antoni Riba Blanch, Antonio Bosquet Álamo, Antonio Camps Selles, Antonio Cuesta Sánchez, Antonio Hernández Ruiz, Antonio Pablo Arenas Vacas, Antonio Rodríguez Celaya, Antonio Tafalla Martín, Antonio Torras Picón, Armand Izquierdo Martínez, Bassam Darwich Muhti, Benigno Del Busto De Lorenzo, Berta Avilés Huertos, Carlos A Aguado Hernández, Carlos Martín Carrasco, Carlos Martínez Rivera, Carlos Millan Sánchez, Carme Santiveri Gilabert, Carmen Soto Fernández, Casimir Money Sánchez, Ceferino Pico López, Celedonio Sobera Echezarreta, 
Cesar Vidal González, Cesáreo López Rodríguez, Claudio Vidal De Mesa, Concepción Pérez Domínguez, Concepción Plans Bolibar, Concepción Rodríguez Fernández, Dámaso Escribano Sevillamo, David Blanques Escribano, David Herrero I Barrera, David Orts Giménez, Demetrio González Vergara, Deopatria Esteban Fresno, Diego Ferrer MarínBlazquez, Domingo Fernández García, Eloy López Neira, Emilio Viudes Plazas, Encarnación Fernández Robledo, Enrique Alvarez-Llaneza García, Enrique José Pérez Parra, Enrique López De Briñas Y Banacloy, Enrique Sardaña Álvarez, Erika Tavera Gómez, Esperanza Martín Zapatero, Faustino Vega Pérez, Felipe Nicolau Pastríe, Félix Martín Santos, Fernando De Arriba Frade, Fernando Dolz Andrés, Fernando 1 Sancho Villanova, Fernando Marco Cardona, Fernando Martí-Vivaldi Martínez, Fernando Mayo Ferreiro, Fernando Sánchez-Toril López, Francisco De Pablo Cillero, Francisco Durán Hernández, Francisco Javier Balda Jauregui, Francisco Javier Bartolomé Resano, Francisco Javier Fernández De Frutos, Francisco Javier Guerra Ramos, Francisco Javier Rodríguez Argüeso, Francisco Javier Tamayo Sicilia, Francisco Luis Gil Muñoz, Francisco Manuel Balaguer Montesinos, Francisco Martos Torres, Francisco Risco Sánchez, Francisco Samuel Fernández Escribano, Francisco Sangenis Biosca, Francisco Vaques Arias, Froilan Sáncez Sánchez, Gador Ramos Villalobos, Gemma Martínez Almagro, Gerardo Estruch Catalá, Germán Fernández López, German Saez Roca, Gonzalo Carles Hueso, Guadalupe Fernández Esteve, Guillermo Pérez Toledo, Gustavo Solince Gallardo, Hugo Dante García Ibarra, Ignacio Abascal Carey, Ignacio J Pérez De Diego, Inés Gil Gil, Irene De Lorenzo García, Isabel Lledó Fillol, Isidro Rodoreda Meillán, Jaime Creixell Sánchez, Javier Amiama Ruiz, Javier Antón Ortega, Javier Gallego Borrego, Javier Gallego Borrego, Jesús Armando Montero Abramonte, Jesús Castillo Ballesteros, Jesús Chamorro Romero, Jesús De La Fuente Pérez, Jesús Pastor Antón, Jesús Picazo Moreno, Jesús Zumeta Fustero, Joan Carle Caballero Domenech, Joan Clotet Solsona, Joan Cornet Sisquella, Joan Juvanteny Gorgals, Joan Ribot Pérez, Joan Ventosa Rodón, Joaquín Ferrandiz Miquel, Joaquín Salazar Vargas, Jorge Jorge Abad Capa, Pascual Bernabeu, José Antonio Carratalá Torregrosa, José Antonio Gómez Marco, José Antonio Martín Bernal, José Antonio Martín Soledad, José Antonio Quintano Jiménez, José Berrocal Del Rio, José Burillo Arias, José Celdrán Gil, José Enrique Gavela García, José Enrique Lezcano Devesa, Jose Ignacio González Castellano, José Luis Colomer Martí, José Luis Del Rio Pedrosa, José Luis Fernández Menéndez, José Luis Rojas Box, José Luis Rojas Box, José Maldonado Díaz De Losada, José Manuel Bretones
Rodríguez, José Manuel Lorente Iniesta, José Manuel Muñoz Malagarriga, José María Esteve Ribelles, José María Jiménez Páez, José María Sánchez Mariscal, José Mario Salabert Rius, José Miguel Durán Durán, José Miguel Durán Durán, José Miguel Grima Barbero, José Pruñonosa Piera, José Sánchez Aldeguer, José Sanz Santos, José Vicente Campos Cristobal, Josep Comerma Barcelo, Josep María Alsina Martín, Josep María Benet Martí, Josep Maria Cuatrecasas Ardid, Josep María Jové Ysanta, Juan Abreu González, Juan Antonio Chavez Plasencia, Juan Antonio Lloret Queraltó, Juan Antonio Martínez Carbonell, Juan Antonio Royo Prats, Juan Antonio Sánchez Palau, Juan B Navarro González, Juan Barón Carrillo, Juan Carles Clara Riart, Juan Carlos Martín La Foz, Juan Enrique Luces Macias, Juan Francisco Andrade Bellido, Juan Francisco De Vega García, Juan Gil Carbonell, Juan Guallar Ballester, Juan Guijo Castro, Juan Hilanderas Jiménez, Juan Jiménez Guillén, Juan José Linares Linares, Juan José Martínez De La Torre, Juan Luis De La Torre Alvaro, Juan Luis García Rivero, Juan Manuel Acosta Méndez, Juan Manuel Meseguer Gil, Juan Manuel Nieto Somoza, Juan Manuel Verdeguer Miralles, Juan Miguel Sampol Company, Juan Ortiz De Saracho Y Boho, Juan Pablo García Muñoz, Juan Ramis Alemany, Juan Suárez Antelo, Juan Viles Valentí, Julia Vazquez Vazquez, Julián Ramón Garrido Jiménez, Julio Antonio García Cañizares, Julio Aurelio Gorriz Nuñez, Julio Portela Carreiro, Justo Grau Delgado, Khaled A Bdeir Egnyem, Larraitz Garcia Echeberria, Lirios Sacristán Bou, Lorenzo Jiménez Alfonso, Lucia Díaz Cañaveral, Lucia Díaz Cañaveral, Luis Antonio González Rodriguez, Luis Camara Cabrerizo, Luis Carlos Aguilar Martínez, Luis Emilio Delgado Torices, Luis M Entrenas Costa, Luis Rodríguez Pascual, Luis Toca Enrique, Luisa Valladares Rodríguez, Maite Andreu Sabdell, Maite Gómara Urdiain, Manuel Carlos Barreiro Mourentan, Manuel Castilla Martínez, Manuel Cervera Del Pino, Manuel Cervera Del Pino, Manuel Ma Liñares Stolle, Manuel Martínez Riaza, Manuel Miquel Palasi, Manuel Ocaña Torres, Manuel Pastor Rull, Manuel Salcedo Espinosa, Manuel Torres Pascual, Manuel Vicente Chincilla, Manuel Vila Justribó, Manuel Vila Justribó, Marc Bonnin Vilapalan, María Begoña Salinas Lasa, María Belén Alonso Ortiz, María Del Carmen Victoria López, Maria Del Pilar Ortega Castillo, María Dolores Gallardo García, María Dolores Mota Godoy, María Eugenia Casado López, María Isabel Parra Parra, María Jesús Avilés Inglés, María José Pericón Puyal, María Lucia Gascón Pedrola, Maria Luisa Moreno Torres, María Luisa Rivera Ortun, María Martínez Ceres, María Rosa Calderer Cardona, Mariano Muñoz Llanez, Marina C Rodríguez Hernández, Marta Palop Cervera, Miguel 
A Martín Pérez, Miguel Ángel Ciscar Vilanova, Miguel Angel García González, Miguel Angél López Aranda, Miguel Angel Palomino Medina, Mireia Vila Santiago, Mishail Dahdouh Kuri, Mónica Cañero Torrecillas, Monserrat Llop Moreno, Monserrat Llordes Llordes, Narciso Fernández Carbajo, Natalia Carretero Suero, Nestor Almeida Pérez, Nur ElHomssi Jarsa, Nuria Castejón Pina, Pascual Llop Usó, Pascual Mañes Vicente, Patricia Lloberes Canadell, Patricia Mata Calderón, Pau Llacér Iborra, Pedro Penela Penela, Pedro Penela Penela, Pedro Baños Hidalgo, Pedro J Romero Palacios, Pedro José De La Paz Gutierre, Pedro José López Villalba, Pedro Martínez Brugada, Pedro Pinto González, Pedro Vicioso Ranz, Pilar Lázaro Gracia, Pilar Marín Martínez, Rafael Belenguer Prieto, Rafael Calvet Madrigal, Rafael Castrodeza Sanz, Rafael Giménez Domenech, Rafael Lama Rodríguez, Rafael Machín Ramírez, Rafael Matoses Marco, Rafael Saez Valls, Rafael V Lluch Mota, Ramón Magarolas Jordá, Ramón Manuel Hernández Sadurní, Ramón Martínez Bretones, Ramón Tarrés Gimferrer, Raquel Llera Guerra, Roberto Veiga Gallego, Rodrigo Abad Rodríguez, Rosa María López Lisbona, Rosa Maria Pérez Nava, Rosario Cortina Rodríguez, Rosario Vargas González, Rossana Satorre Tomás, Rubén Andújar Espinosa, Rubén Saurent Helman, Salvador Bertran Folqué, Salvador Ruso Pacheco, Santiago Carrizo Sierra, Santiago Otaduy Bengoa, Sebastiana Pérez Rodríguez, Sergio Campos Téllez, Sergio Gallego Piote, Sergio Salvadó Vives, Silvia Molina Aguileras, Sonia Martínez Sáez, Teresa López Sangil, Teresa Peña Miguel, Tomás Lloret Pérez, Valentin Atxotegui Iraolagoitia, Valentina Moggi Zafferani, Vicente Gallego Rodríguez, Vicente Gomar Andrés, Vicente José Roig Figueroa, Vicente López Escrivá, Vicente Penades Vaya, Vicente Poveda Gran, Victor Jiménez Castro, Victor Vera Campillo, Virginia Serrano Gutierrez, Xavier Alfaro Rodriguez, Xavier Arnal Marcé, Xavier Casals Reynals, Xavier Martínez Álvarez, Xavier Ureta I Boixadera, Xavier Vilá Giralte, Xavier Vila Reyner, Yolanda Galea Colón.

\section{Disclosure}

Carlos Roncero has received fees to give talks for JanssenCilag, Bristol-Myers Squibb, Ferrer-Brainfarma, Pfizer, Reckitt Benckiser, Lundbeck, Otsuka, Servier, Lilly, GlaxoSmithKline, Rovi, and Adamed. He has received financial compensation for his participation as a board member of Janssen-Cilag, Lilly, and Shire. He conducted the PROTEUS project, which was funded by a grant from Reckitt-Benckisert. Ana Isabel Campuzano and Joselín Pérez are full-time employees of Grupo Ferrer (Barcelona, Spain). José Antonio Quintano received speaker fees from Almirall, Bayer, Boehringuer Ingelheim, Ferrer, GlaxoSmithKline, Novartis,
Menarini, TEVA, and consulting fees from Almirall, Boehringuer Ingelheim, Ferrer, Menarini, Novartis, Mundipharma, and received registration for medical congresses from Almirall, Pfizer, Gebro, GlaxoSmithKline, Mundipharma, Novartis, and Rovi. Jesús Molina has received speaker fees from AstraZeneca, Boehringer Ingelheim, Chiesi, GlaxoSmithKline, Novartis, Mundifarma, Pfizer, and consulting fees from Boehringer Ingelheim, Gebro Pharma, Mundifarma, and GlaxoSmithKline. Marc Miravitlles has received speaker fees from Almirall, Boehringer Ingelheim, Pfizer, AstraZeneca, Chiesi, Esteve, GlaxoSmithKline, Menarini, Novartis, Talecris-Grifols, Takeda-Nycomed, and Novartis, and consulting fees from Almirall, Boehringer Ingelheim, Pfizer, GlaxoSmithKline, Gebro Pharma, MediImmune, Novartis, Talecris-Grifols, and Takeda-Nycomed.

The DEPREPOC study was funded by Grupo Ferrer (Barcelona, Spain). The study sponsor had no involvement in study design, collection, analysis, and interpretation of data, in the writing of the manuscript, or in the decision to submit the manuscript for publication. This was the initiative of the authors. The authors report no other conflicts of interest in this work.

\section{References}

1. GOLD. Global Strategy for the Diagnosis, Management, and Prevention of Chronic Obstructive Pulmonary Disease. Updated 2014. 2014. Available from: http:/www.goldcopd.org/uploads/users/files/ GOLD_Report_2014.pdf. Accessed June 16, 2015.

2. Divo M, Cote C, de Torres JP, et al. Comorbidities and risk of mortality in patients with chronic obstructive pulmonary disease. Am J Respir Crit Care Med. 2012;186(2):155-161.

3. Brenes GA. Anxiety and chronic obstructive pulmonary disease: prevalence, impact, and treatment. Psychosom Med. 2003;65(6):963-970.

4. Zhang MWB, Ho RCM, Cheung MWL, Fu E, Mak A. Prevalence of depressive symptoms in patients with chronic obstructive pulmonary disease: a systematic review, meta-analysis and meta-regression. Gen Hosp Psychiatry. 2011;33(3):217-223.

5. Cleutjens FA, Janssen DJ, Ponds RW, Dijkstra JB, Wouters EF. COgnitive-pulmonary disease. Biomed Res Int. 2014;2014:697825.

6. Antonelli-Incalzi R, Gemma A, Marra C, Capparella O, Fuso L, Carbonin P. Verbal memory impairment in COPD: its mechanisms and clinical relevance. Chest. 1997;112(6):1506-1513.

7. Allen SC, Jain M, Ragab S, Malik N. Acquisition and short-term retention of inhaler techniques require intact executive function in elderly subjects. Age Ageing. 2003;32(3):299-302.

8. Antonelli-Incalzi R, Corsonello A, Pedone C, et al. Drawing impairment predicts mortality in severe COPD. Chest. 2006;130(6):1687-1694.

9. Dodd JW, Getov SV, Jones PW. Cognitive function in COPD. Eur Respir J. 2010;35(4):913-922.

10. Dodd JW, Charlton RA, van den Broek MD, Jones PW. Cognitive dysfunction in patients hospitalized with acute exacerbation of COPD. Chest. 2013;144(1):119-127.

11. Miravitlles M, Molina J, Quintano JA, Campuzano A, Perez J, Roncero C. Factors associated with depression and severe depression in patients with COPD. Respir Med. 2014;108(11):1615-1625.

12. Bestall J, Paul E, Garrod R, Garnham R, Jones P, Wedzicha J. Usefulness of the Medical Research Council (MRC) dyspnoea scale as a measure of disability in patients with chronic obstructive pulmonary disease. Thorax. 1999;54(7):581-586. 
13. Soler-Cataluña JJ, Martínez-García MÁ, Sánchez LS, Tordera MP, Sánchez PR. Severe exacerbations and BODE index: two independent risk factors for death in male COPD patients. Respir Med. 2009;103(5):692-699.

14. Charlson ME, Pompei P, Ales KL, MacKenzie CR. A new method of classifying prognostic comorbidity in longitudinal studies: development and validation. J Chronic Dis. 1987;40(5):373-383.

15. Folstein MF, Folstein SE, McHugh PR. "Mini-mental state". A practical method for grading the cognitive state of patients for the clinician. J Psychiatr Res. 1975;12(3):189-198.

16. Lobo A, Saz P, Marcos G, et al. Revalidación y normalización del MiniExamen Cognoscitivo (primera versión en castellano del Mini-Mental Status Examination) en la población general geriátrica [Revalidation and standardization of the cognition mini-exam (first Spanish version of the Mini-Mental Status Examination) in the general geriatric population]. Med Clin(Barc). 1999;112(20):767-774. Spanish.

17. Villeneuve S, Pepin V, Rahayel S, et al. Mild cognitive impairment in moderate to severe COPD: a preliminary study. Chest. 2012;142(6): 1516-1523.

18. Beck AT, Steer RA, Carbin MG. Psychometric properties of the Beck Depression Inventory: twenty-five years of evaluation. Clin Psycho Rev. 1988;8(1):77-100.

19. Bonilla J, Bernal G, Santos A, Santos D. A revised Spanish version of the Beck Depression Inventory: psychometric properties with a Puerto Rican sample of college students. J Clin Psychol. 2004;60(1):119-130.

20. Badia X, Roset M, Montserrat S, Herdman M, Segura A. The Spanish version of EuroQol: a description and its applications. European Quality of Life scale. Med Clin(Barc). 1999;112(Suppl 1):79-85.

21. Jones PW, Harding G, Berry P, Wiklund I, Chen WH, Kline Leidy N. Development and first validation of the COPD Assessment Test. Eur Respir J. 2009;34(3):648-654.

22. Jones PW, Brusselle G, Dal Negro RW, et al. Properties of the COPD assessment test in a cross-sectional European study. Eur Respir J. 2011 38(1):29-35.

23. Esteban C, Quintana JM, Aburto M, et al. Impact of changes in physical activity on health-related quality of life among patients with COPD. Eur Respir J. 2010;36(2):292-300.

24. Miravitlles M, Cantoni J, Naberan K. Factors associated with a low level of physical activity in patients with chronic obstructive pulmonary disease. Lung. 2014;192(2):259-265.

25. Roca M, Monzon S, Vives M, et al. Cognitive function after clinical remission in patients with melancholic and non-melancholic depression: a 6 month follow-up study. J Affect Disord. 2015;171:85-92.

26. Jacewicz MM, Hartley AA. Age differences in the speed of cognitive operations: resolution of inconsistent findings. J Gerontol. 1987;42(1): 86-88.

27. Hung WW, Wisnivesky JP, Siu AL, Ross JS. Cognitive decline among patients with chronic obstructive pulmonary disease. Am J Respir Crit Care Med. 2009;180(2):134-137.

28. Thakur N, Blanc PD, Julian LJ, et al. COPD and cognitive impairment: the role of hypoxemia and oxygen therapy. Int J Chron Obstruct Pulmon Dis. 2010;5:263-269.

29. Ortapamuk H, Naldoken S. Brain perfusion abnormalities in chronic obstructive pulmonary disease: comparison with cognitive impairment Annals Nucl Med. 2006;20(2):99-106.
30. Dal Negro RW, Bonadiman L, Bricolo FP, Tognella S, Turco P. Cognitive dysfunction in severe chronic obstructive pulmonary disease (COPD) with or without Long-Term Oxygen Therapy (LTOT). Multidiscip Respir Med. 2015;10(1):17.

31. Parekh PI, Blumenthal JA, Babyak MA, et al. Gas exchange and exercise capacity affect neurocognitive performance in patients with lung disease. Psychosom Med. 2005;67(3):425-432.

32. Gibson GE, Pulsinelli W, Blass JP, Duffy TE. Brain dysfunction in mild to moderate hypoxia. Am J Med. 1981;70(6):1247-1254.

33. Maccioni RB, Rojo LE, Fernandez JA, Kuljis RO. The role of neuroimmunomodulation in Alzheimer's disease. Ann N Y Acad Sci. 2009;1153: 240-246.

34. Weuve J, Glymour MM, Hu H, et al. Forced expiratory volume in 1 second and cognitive aging in men. J Am Geriatr Soc. 2011;59(7): 1283-1292.

35. Miravitlles M, Peña-Longobardo LM, Oliva-Moreno J, Hidalgo-Vega Á. Caregivers' burden in patients with COPD. Int J Chron Obstruct Pulmon Dis. 2015;10:347-356.

36. Petersen RC, Roberts RO, Knopman DS, et al. Mild cognitive impairment: ten years later. Arch Neurol. 2009;66(12):1447-1455.

37. Antonelli-Incalzi R, Corsonello A, Pedone C, Corica F, Carbonin P, Bernabei R. Construct validity of activities of daily living scale: a clue to distinguish the disabling effects of COPD and congestive heart failure. Chest. 2005;127(3):830-838.

38. Fix AJ, Daughton D, Kass I, Bell CW, Golden CJ. Cognitive functioning and survival among patients with chronic obstructive pulmonary disease. Int J Neurosci. 1985;27(1-2):13-17.

39. Miravitlles M, Garcia-Polo C, Domenech A, Villegas G, Conget F, de la Roza C. Clinical outcomes and cost analysis of exacerbations in chronic obstructive pulmonary disease. Lung. 2013;191(5):523-530.

40. Miravitlles M, Calle M, Alvarez-Gutierrez F, Gobartt E, Lopez F, Martin A. Exacerbations, hospital admissions and impaired health status in chronic obstructive pulmonary disease. Qual Life Res. 2006; 15(3):471-480.

41. Halpin DM, Decramer M, Celli B, Kesten S, Liu D, Tashkin DP. Exacerbation frequency and course of COPD. Int J Chron Obstruct Pulmon Dis. 2012;7:653-661.

42. Ambrosino N, Bruletti G, Scala V, Porta R, Vitacca M. Cognitive and perceived health status in patient with chronic obstructive pulmonary disease surviving acute on chronic respiratory failure: a controlled study. Intensive Care Med. 2002;28(2):170-177.

43. Kirkil G, Tug T, Ozel E, Bulut S, Tekatas A, Muz MH. The evaluation of cognitive functions with P300 test for chronic obstructive pulmonary disease patients in attack and stable period. Clin Neurol Neurosurg 2007;109(7):553-560.

44. Lopez-Torres I, Valenza MC, Torres-Sanchez I, Cabrera-Martos I, Rodriguez-Torres J, Moreno-Ramirez MP. Changes in cognitive status in COPD patients across clinical stages. COPD. 2015:1-6. [Epub ahead of print].

45. Gan WQ, Man SF, Senthilselvan A, Sin DD. Association between chronic obstructive pulmonary disease and systemic inflammation: a systematic review and a meta-analysis. Thorax. 2004;59(7):574-580.

46. Kelleher RJ, Soiza RL. Evidence of endothelial dysfunction in the development of Alzheimer's disease: is Alzheimer's a vascular disorder? Am J Cardiovasc Dis. 2013;3(4):197-226.
International Journal of COPD

\section{Publish your work in this journal}

The International Journal of COPD is an international, peer-reviewed journal of therapeutics and pharmacology focusing on concise rapid reporting of clinical studies and reviews in COPD. Special focus is given to the pathophysiological processes underlying the disease, intervention programs, patient focused education, and self management protocols.

\section{Dovepress}

This journal is indexed on PubMed Central, MedLine and CAS. The manuscript management system is completely online and includes a very quick and fair peer-review system, which is all easy to use. Visit http://www.dovepress.com/testimonials.php to read real quotes from published authors. 